\title{
Tribological Behavior of TiAl-Multilayer Graphene-Ag Composites at Different Temperatures and Sliding Speeds
}

\author{
Jia-Liang Zou ${ }^{1} \cdot$ Xiao-Liang Shi $^{1} \cdot$ Qiao Shen ${ }^{1} \cdot$ Kang Yang $^{1} \cdot$ Yu-Chun Huang ${ }^{1} \cdot$ Ao Zhang $^{1} \cdot$ Yu-Fu Wang ${ }^{1} \cdot$ \\ Qiao-Xin Zhang ${ }^{1}$
}

Received: 22 August 2016/Revised: 8 October 2016/Published online: 13 February 2017

(C) The Chinese Society for Metals and Springer-Verlag Berlin Heidelberg 2017

\begin{abstract}
Tribological behavior of TiAl-multilayer graphene-Ag composites (TMACs) prepared by spark plasma sintering against a $\mathrm{Si}_{3} \mathrm{~N}_{4}$ ball was investigated on a ball-on-disk high-temperature tribometer at different test temperatures and sliding speeds in this study. The test results showed that TMACs had the lower friction coefficient and less wear rate at $450{ }^{\circ} \mathrm{C}-0.25 \mathrm{~m} / \mathrm{s}$, which was attributed to the formation of the high-strength and intact tribofilms on worn surface. At $450{ }^{\circ} \mathrm{C}-0.25 \mathrm{~m} / \mathrm{s}$, during the sliding process, multilayer graphene (MLG) was ground out to form the high-strength skeletons on the worn surface of TMACs. Ag was migrated from the worn surface and combined with the MLG skeleton to form the high-strength and intact tribofilms. The high-strength and intact tribofilms were beneficial to lowering the friction coefficient for the lubricating effect of $\mathrm{Ag}$ and decreasing wear rate for the enhancing effect of MLG skeleton.
\end{abstract}

KEY WORDS: Solid lubricant additives; Self-lubricating composites; Self-lubricated; Wear

\section{Introduction}

TiAl alloys have been considered as the new lightweight structural material, which would be widely applied in the industries of aerospace and automobiles due to the excellent properties, such as low density, high specific strength, good oxidation resistance and high-temperature strength [1]. However, the further applications of TiAl alloys may be limited because of the poor tribological performance. Hence, several methods, such as liquid lubricants $[2,3]$ and thermally oxidized treatment [4], had been used to improve the friction and wear properties of TiAl alloys. However, liquid lubricants could not meet the advanced requirements

Jia-Liang Zou and Kang Yang have contributed equally to this work.

Available online at http://link.springer.com/journal/40195

Xiao-Liang Shi

sx1071932@126.com

1 School of Mechanical and Electronic Engineering, Wuhan University of Technology, Wuhan 430070, China at high temperature due to the lubrication failure caused by the rapid decrease in oil viscosity. Thermally oxidized treatment may not be suitable in long-term industrial applications due to the limited service life. Self-lubricating composites containing solid lubricants could overcome these shortcomings owing to the excellent self-lubricating properties at elevated temperatures and under long-time work conditions. Yang et al. [5] investigated the tribological behavior of $\mathrm{Al}_{2} \mathrm{O}_{3} / \mathrm{TiC} / \mathrm{CaF}_{2}-\mathrm{Al}_{2} \mathrm{O}_{3} / \mathrm{TiC}$-laminated ceramic composites prepared by cold pressing and sintering and reported that $\mathrm{Al}_{2} \mathrm{O}_{3} / \mathrm{TiC} / \mathrm{CaF}_{2}-\mathrm{Al}_{2} \mathrm{O}_{3} / \mathrm{TiC}$-laminated ceramic composites exhibited smaller friction coefficient and lower wear rate than those of $\mathrm{Al}_{2} \mathrm{O}_{3} / \mathrm{TiC}$ ceramic after the addition of solid lubricant $\mathrm{CaF}_{2}$. Zhang et al. [6] studied the wear performance of $\mathrm{NiCr} / \mathrm{AgVO}_{3}$ self-lubricating composites and found that $\mathrm{NiCr} / \mathrm{AgVO}_{3}$ showed the better tribological behavior than $\mathrm{NiCr}$ alloy from 25 to $800{ }^{\circ} \mathrm{C}$ mainly due to the lubricating effect of $\mathrm{AgVO}_{3}$.

Ag with low shear strength was widely used as a solid lubricant to improve the tribological performance of materials. Ouyang et al. [7] studied the tribological 
performance of $\mathrm{ZrO}_{2}\left(\mathrm{Y}_{2} \mathrm{O}_{3}\right)-\mathrm{CaF}_{2}-\mathrm{Ag}$ composites from 25 to $800{ }^{\circ} \mathrm{C}$. The results showed that the addition of $\mathrm{Ag}$ and $\mathrm{CaF}_{2}$ was beneficial to the formation of a well-covered lubricating film, resulting in the decrease in friction and wear. Shi et al. [8] adopted Ag as the solid lubricant to improve the tribological behavior of TiAl matrix composites (TMCs) and found that solid lubricant Ag could decrease the friction coefficients of TMCs at elevated temperatures. Moreover, multilayer graphene (MLG) also could serve as a solid lubricant. Penkov et al. [9] reported that graphene could play an effective role in reducing the friction and wear under microscale contact loads and relatively high loads. Wang et al. [10] investigated the tribological performance of the MLG-filled poly (vinyl chloride) composites and reported that MLG could decrease the friction coefficient and wear rate of the MLG/ PVC composites. Xu et al. [11] reported that MLG, which was easy to be sheared to form an anti-wear film, could decrease the friction coefficients and wear rates of TMCs. Hence, lubricants Ag and MLG were adopted to improve the tribological performance of TMCs.

It is well known that tribological performance is not only the inter-property of a material but also the system response to the test conditions, such as test temperature and sliding speed. Several studies have reported the influence of sole parameter on the tribological behaviors. Cheng et al. [12] investigated the tribological performance of $\mathrm{Ti}-46 \mathrm{Al}-2 \mathrm{Cr}-$ $2 \mathrm{Nb}$ intermetallics at high temperatures and reported that the wear rate of $\mathrm{Ti}-46 \mathrm{Al}-2 \mathrm{Cr}-2 \mathrm{Nb}$ intermetallics was related to the test temperatures. The wear rate increased with the increase in temperature from 20 to $400{ }^{\circ} \mathrm{C}$ and then decreased at 600 and $700{ }^{\circ} \mathrm{C}$. Chowdhury et al. [13] studied the effects of sliding speed and normal load on friction and wear performance of aluminum. The results showed that the friction coefficient decreased but the wear rate increased with the increase in sliding speed. Cheng et al. [3] investigated the tribological behavior of $\mathrm{Ti}-46 \mathrm{Al}-2 \mathrm{Cr}-2 \mathrm{Nb}$ and found that wear rate of $\mathrm{Ti}-46 \mathrm{Al}-2 \mathrm{Cr}-2 \mathrm{Nb}$ first decreased and then increased with the increase in sliding speed. Meanwhile, it should be noted that the temperature and sliding speed may change simultaneously in the actual work occasion, which may have great impact on the tribological behaviors of TMCs. Nevertheless, few studies reported the combined effects of test temperature and sliding speed on the tribological properties of TMCs. In our previous experience, TMCs had a good tribological performance at $12 \mathrm{~N}$ [14]. Meanwhile, it was better to choose the test temperature from 20 to $600{ }^{\circ} \mathrm{C}$ and sliding speed from 0.10 to $0.30 \mathrm{~m} / \mathrm{s}$ to study the tribological performance of TMCs. Therefore, in this paper, the tribological performances of TiAl-multilayer graphene-Ag composites (TMACs), sliding against a 6-mm-diameter $\mathrm{Si}_{3} \mathrm{~N}_{4}$ ball on a ball-on-disk tribometer at $12 \mathrm{~N}, \quad$ at $25^{\circ} \mathrm{C}-0.10 \mathrm{~m} / \mathrm{s}, \quad 150{ }^{\circ} \mathrm{C}-0.15 \mathrm{~m} / \mathrm{s}, \quad 300{ }^{\circ} \mathrm{C}-$
$0.20 \mathrm{~m} / \mathrm{s}, \quad 450{ }^{\circ} \mathrm{C}-0.25 \mathrm{~m} / \mathrm{s}$ and $600{ }^{\circ} \mathrm{C}-0.30 \mathrm{~m} / \mathrm{s}$ were studied. Besides, the formation and effect mechanisms of tribofilms were also investigated.

\section{Experimental Details}

\subsection{Material Preparation}

TMACs were prepared by spark plasma sintering (SPS) using a D.R.Sinter ${ }^{\circledR}$ SPS3.20 (Sumitomo Coal \& Mining, now SPS Syntex Inc.) apparatus. It was known that alloying, e.g., the addition of $\mathrm{Nb}, \mathrm{Cr}$, and $\mathrm{B}$, could effectively improve the chemical and mechanical properties of TiAl alloys. Among these elements, Nb improved not only the creep resistance and room temperature toughness of TiAl alloys, but also the oxidation resistance [15]. Hence, commercial powders $\mathrm{Ti}(20 \mu \mathrm{m}$ in average size, $99.9 \%$ in purity), Al (20 $\mathrm{m}$ in average size, $99.9 \%$ in purity), $\mathrm{Cr}$ (10 $\mu \mathrm{m}$ in average size, $99.9 \%$ in purity), $\mathrm{Nb}(10 \mu \mathrm{m}$ in average size, $99.9 \%$ in purity), B (25 $\mu \mathrm{m}$ in average size, $99.9 \%$ in purity), Ag (25 $\mu \mathrm{m}$ in average size, $99.9 \%$ in purity) and MLG (average thickness of $40 \mathrm{~nm}$ and average lateral dimension of $50 \mu \mathrm{m}$ ) were used in this study. The molar ratio of $\mathrm{Ti}, \mathrm{Al}, \mathrm{Cr}, \mathrm{Nb}$ and $\mathrm{B}$ was 48:47:2:2:1. The weight fractions of $\mathrm{Ag}$ and MLG in TMACs were 5 and 1.5 wt $\%$, respectively. The commercial powders were mixed by vibration milling with the vibration frequency of $45 \mathrm{~Hz}$ for $15 \mathrm{~min}$ before being sintered. Then, the mixture powders were put into a cylindrical graphite mold with an inner diameter of $20 \mathrm{~mm}$ to be sintered for $10 \mathrm{~min}$ in pure $\mathrm{Ar}$ atmosphere protection under $30 \mathrm{MPa}$. The heating rate was $100{ }^{\circ} \mathrm{C} / \mathrm{min}$, and the sintering temperature was $1100{ }^{\circ} \mathrm{C}$. The surface of as-prepared specimens was ground to clear the graphite layer and polished mechanically with emery papers down to 1200 grit.

\subsection{Vickers Hardness and Density}

According to the ASTM standard E92-82 [16], the Vickers hardness of each sample was measured using a Vickers hardness instrument (HVS-1000, Changzhou detu Precision Instrument Co Ltd., China) with a load of $1 \mathrm{~kg}$ and a dwell time of $10 \mathrm{~s}$. Each sample was repeatedly tested for eight times to obtain the mean value of 396.4 HV1. The density was determined by the Archimedes' principle according to the ASTM standard B962-08 [17]. The mean value was $3.95 \mathrm{~g} / \mathrm{mm}^{3}$.

\subsection{Tribological Tests}

Tribological tests were carried out on a ball-on-disk hightemperature tribometer (HT-1000, Zhong Ke Kai Hua 
Corporation, China) in ambient environment (humidity $50 \%-55 \%$ ) under $12 \mathrm{~N}$ for $80 \mathrm{~min}$ at $25^{\circ} \mathrm{C}-0.10 \mathrm{~m} / \mathrm{s}$, $150{ }^{\circ} \mathrm{C}-0.15 \mathrm{~m} / \mathrm{s}, 300{ }^{\circ} \mathrm{C}-0.20 \mathrm{~m} / \mathrm{s}, 450{ }^{\circ} \mathrm{C}-0.25 \mathrm{~m} / \mathrm{s}$ and $600{ }^{\circ} \mathrm{C}-0.30 \mathrm{~m} / \mathrm{s}$, respectively. The disks were the as-prepared samples. The counterparts were commercially available $\mathrm{Si}_{3} \mathrm{~N}_{4}$ balls with a diameter of $6 \mathrm{~mm}$. The hardness of $\mathrm{Si}_{3} \mathrm{~N}_{4}$ balls (15 GPa) was remarkably larger than that of TMACs, which was beneficial to reflecting the tribological behaviors of TMACs. The surfaces of $\mathrm{Si}_{3} \mathrm{~N}_{4}$ balls were polished to an average surface roughness (Ra) of $0.01 \mu \mathrm{m}$. Before the dry friction test, both $\mathrm{Si}_{3} \mathrm{~N}_{4}$ balls and as-prepared samples were cleaned with alcohol and then dried in hot air. The friction coefficients were automatically measured and recorded in real time by the computer system of the friction tester. Wear rate was calculated by the following formula:

$W=\frac{V}{P S}$,

where $W$ referred to the wear volume in $\mathrm{mm}^{3}, P$ referred to the testing load in $\mathrm{N}$, and $S$ referred to total sliding distance in $\mathrm{m}$. The profiles of the worn scar cross sections were measured eight times by using a surface profilometer (ST400, Nanovea, USA) to determine the wear volume. The wear volumes were determined by the following formula:

$V=A L$,

where $A$ referred to cross-section area of the worn scar in $\mathrm{mm}^{2}$ and $L$ referred to the perimeter of the worn track in $\mathrm{mm}$.

\subsection{Microstructure Analysis}

X-ray diffraction (XRD, D/MAX-RB, RIGAKU Corporation, Japan) at $30 \mathrm{kV}$ and $40 \mathrm{~mA}$ was used to analyze the constitution of composites. The scanning speed was $0.01 \%$. The field-emission scanning electron microscopy (FESEM, ULTRA-PLUS-43-13, Zeiss Corporation, Germany) was used to analyze the worn surfaces and the cross sections of wear scars. Electron probe microanalyzer (EPMA, JXA-8230, JEOL Corporation, Japan) and energy-dispersive spectroscopy (EDS, Inca X-Act, Oxford Instruments, Britain) were used to analyze the wear scars.

In order to decrease the damage of material structures, the cross-section structures of wear scars were obtained using the method of cooling fracture. Firstly, the samples were incised down to the residual thickness about $1-1.5 \mathrm{~mm}$ at the relative side of wear scars. After being incised, the samples were cooled for $50 \mathrm{~min}$ by using liquid nitrogen. The cooled samples were broken by shearing force under dust-free environment.

\section{Results and Discussion}

\subsection{Microstructure and Elemental Distributions of TMACs}

Figure 1 shows the XRD pattern of TMACs. As shown in Fig. 1, TMACs were mainly composed of $\mathrm{TiAl}, \mathrm{Ag}$ and MLG, as well as small amount of TiC phases. The peaks of TiAl, Ag, MLG and TiC were identified and assigned using the JCPDS cards No. 05-0678, 04-0783, 26-1079 and $32-1383$, respectively. The microstructure and elemental distributions of TMACs analyzed using EDS are shown in Fig. 2. As shown in Fig. 2, Ti, Al, C and Ag elements were homogeneously distributed on the surface of TMACs, suggesting that TMACs should have good mechanical and tribological properties. The cross-section surface morphologies of TMACs observed by FESEM are shown in Fig. 3. Figure 3a shows the typical FESEM morphology of cross section of TMACs. Figure $3 \mathrm{~b}$ shows the high magnification image performed for the area marked by the rectangle in Fig. 3a. As shown in Fig. 3, the MLG was well bonded with TiAl matrix, which was beneficial to improving the mechanical and tribological behavior of TMACs.

\subsection{Tribological Performance of TMACs}

In order to study the tribological performance of TMACs, the dry sliding tests were carried out on a high-temperature tribometer under $12 \mathrm{~N}$ at $25^{\circ} \mathrm{C}-0.10 \mathrm{~m} / \mathrm{s}, 150{ }^{\circ} \mathrm{C}-0.15 \mathrm{~m} / \mathrm{s}$, $300{ }^{\circ} \mathrm{C}-0.20 \mathrm{~m} / \mathrm{s}, 450{ }^{\circ} \mathrm{C}-0.25 \mathrm{~m} / \mathrm{s}$ and $600{ }^{\circ} \mathrm{C}-0.30 \mathrm{~m} / \mathrm{s}$, respectively. Figure 4 shows the dynamic and mean friction coefficients of TMACs under different conditions. As shown in Fig. 4, the friction coefficients of TMACs decreased as

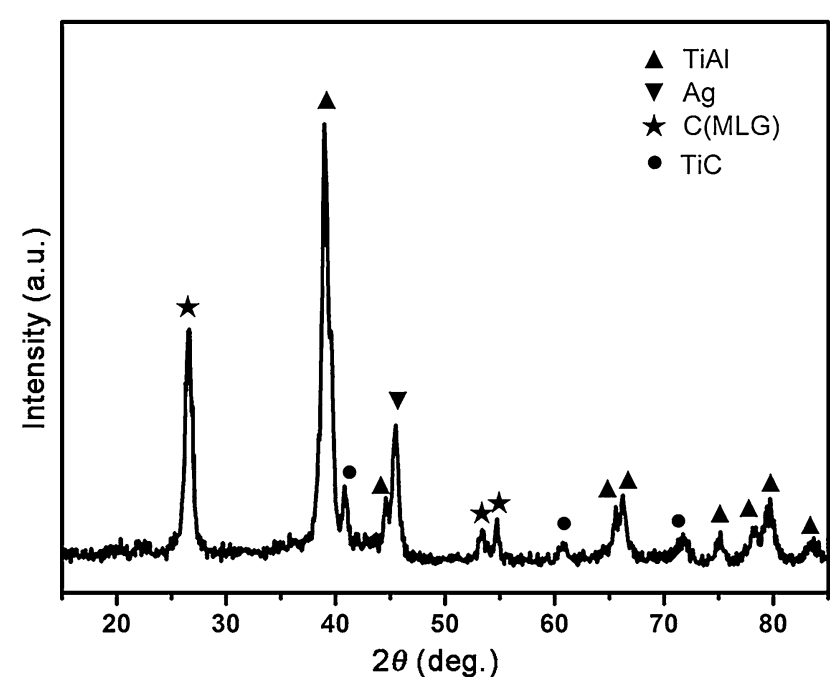

Fig. 1 XRD pattern of TMACs 


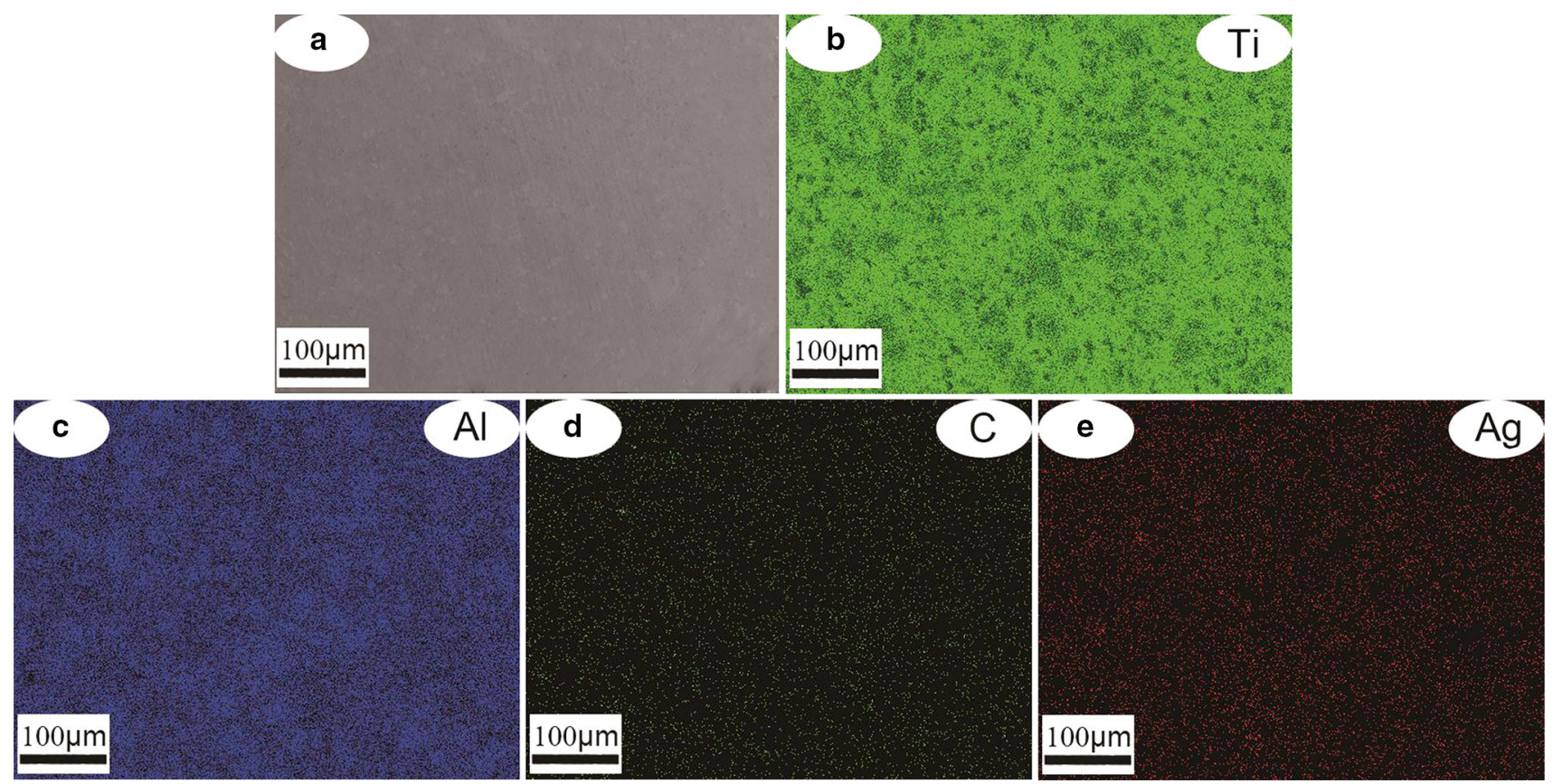

Fig. 2 Microstructure and elemental distributions of TMACs
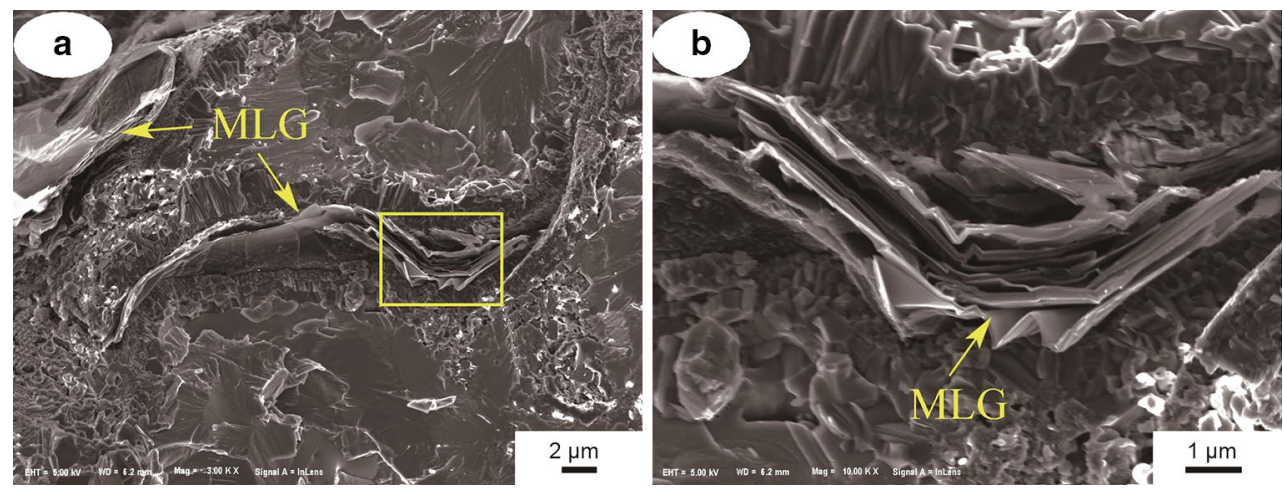

Fig. 3 FESEM morphologies of cross-section surface of TMACs a and high magnification $\mathbf{b}$ of the area marked by rectangle in a

the test condition changed from $25^{\circ} \mathrm{C}-0.10 \mathrm{~m} / \mathrm{s}$ to $450{ }^{\circ} \mathrm{C}-$ $0.25 \mathrm{~m} / \mathrm{s}$, and then increased at $600{ }^{\circ} \mathrm{C}-0.30 \mathrm{~m} / \mathrm{s}$. It can be seen that TMACs showed the smallest friction coefficient (0.29) at $450{ }^{\circ} \mathrm{C}-0.25 \mathrm{~m} / \mathrm{s}$, compared with those at $25^{\circ} \mathrm{C}-$ $0.10 \mathrm{~m} / \mathrm{s}, 150{ }^{\circ} \mathrm{C}-0.15 \mathrm{~m} / \mathrm{s}, 300{ }^{\circ} \mathrm{C}-0.20 \mathrm{~m} / \mathrm{s}$ and $600{ }^{\circ} \mathrm{C}-$ $0.30 \mathrm{~m} / \mathrm{s}$. Figure 5 shows the wear rates of TMACs under different conditions. As shown in Fig. 5, the wear rate of TMACs decreased as the testing condition changed from $25{ }^{\circ} \mathrm{C}-0.10 \mathrm{~m} / \mathrm{s}$ to $450{ }^{\circ} \mathrm{C}-0.25 \mathrm{~m} / \mathrm{s}$, and then increased at $600{ }^{\circ} \mathrm{C}-0.30 \mathrm{~m} / \mathrm{s}$. TMACs showed the smallest wear rate $\left(1.70 \times 10^{-4} \mathrm{~mm}^{3} \mathrm{~N}^{-1} \mathrm{~m}^{-1}\right)$ at $450{ }^{\circ} \mathrm{C}-0.25 \mathrm{~m} / \mathrm{s}$, compared with those at $25^{\circ} \mathrm{C}-0.10 \mathrm{~m} / \mathrm{s}, 150{ }^{\circ} \mathrm{C}-0.15 \mathrm{~m} / \mathrm{s}$, $300{ }^{\circ} \mathrm{C}-0.20 \mathrm{~m} / \mathrm{s}$ and $600{ }^{\circ} \mathrm{C}-0.30 \mathrm{~m} / \mathrm{s}$. According to the tribological test results, it indicated that the tribological behavior of TMACs was related to the testing condition. In order to study the corresponding mechanisms, the element contents and morphologies of worn surfaces were further investigated.

Figure 6 shows the typical EPMA morphologies of worn surfaces obtained after 80 -min test at $25^{\circ} \mathrm{C}-0.10 \mathrm{~m} / \mathrm{s}$, $150{ }^{\circ} \mathrm{C}-0.15 \mathrm{~m} / \mathrm{s}, 300{ }^{\circ} \mathrm{C}-0.20 \mathrm{~m} / \mathrm{s}, 450{ }^{\circ} \mathrm{C}-0.25 \mathrm{~m} / \mathrm{s}$ and $600{ }^{\circ} \mathrm{C}-0.30 \mathrm{~m} / \mathrm{s}$. As shown in Fig. $6 \mathrm{a}$, at $25^{\circ} \mathrm{C}-0.10 \mathrm{~m} / \mathrm{s}$, there were many grooves and wear debris on the worn surface. It indicated that the main wear mechanism was furrow and abrasive wear. The reason may be that the hardness of protrusions on the surface of $\mathrm{Si}_{3} \mathrm{~N}_{4}$ ball was remarkably larger than that of TMACs. Hence, those protrusions were easy to stab into the surface of TMACs. By proceeding the test, part of TMACs would be peeled off from the worn surface by the protrusions, leading to the formation of groove and wear debris. As shown in Fig. 6b$\mathrm{d}$, the grooves gradually became shallow. In addition, the 

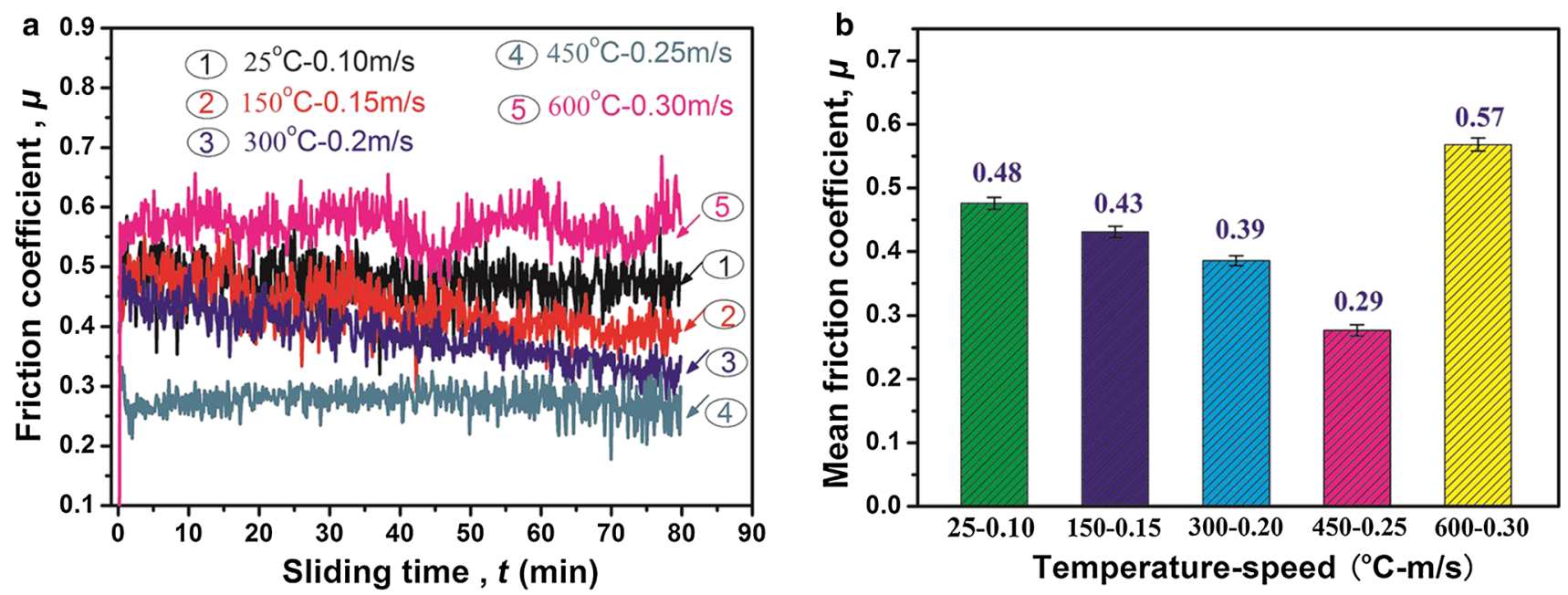

Fig. 4 Dynamic friction coefficient curves a and mean friction coefficients $\mathbf{b}$ of TMACs under different conditions

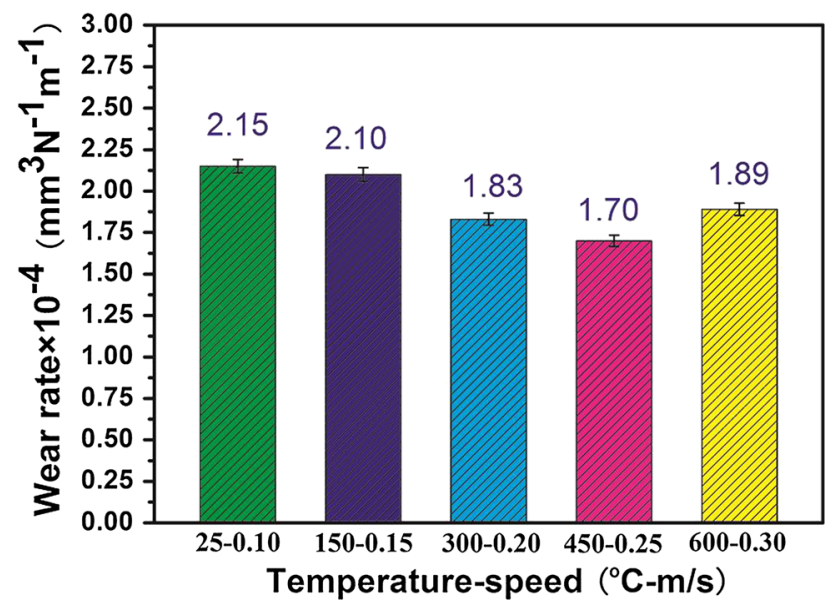

Fig. 5 Wear rates of TMACs under different conditions

smooth tribofilms were gradually formed on the worn surface of TMACs as the test conditions varied from $150{ }^{\circ} \mathrm{C}-$ $0.15 \mathrm{~m} / \mathrm{s}$ to $450{ }^{\circ} \mathrm{C}-0.25 \mathrm{~m} / \mathrm{s}$. At $600{ }^{\circ} \mathrm{C}-0.30 \mathrm{~m} / \mathrm{s}$, as shown in Fig. 6e, the tribofilms were broken under the effect of the applied load, leading to the formation of serious deformation and big peeling pits on the worn surface. The main wear mechanism was plastic deformation. From above observation of EPMA morphologies, it indicated that the different test conditions had obvious effects on the formation and destruction of the tribofilms, resulting in the different friction and wear performance of TMACs. Hence, it was necessary to investigate the composition and microstructure of the tribofilms on worn surfaces of TMACs obtained after tests under different conditions.

The compositions of the tribofilms on the worn surfaces of TMACs were studied by EDS. Figure 7 shows the EDS analysis results of the tribofilms obtained after 80-min test at $25^{\circ} \mathrm{C}-0.10 \mathrm{~m} / \mathrm{s}, \quad 150{ }^{\circ} \mathrm{C}-0.15 \mathrm{~m} / \mathrm{s}, \quad 300{ }^{\circ} \mathrm{C}-0.20 \mathrm{~m} / \mathrm{s}$, $450{ }^{\circ} \mathrm{C}-0.25 \mathrm{~m} / \mathrm{s}$ and $600{ }^{\circ} \mathrm{C}-0.3 \mathrm{~m} / \mathrm{s}$. As shown in Fig. 7 , as the test conditions varied from $25^{\circ} \mathrm{C}-0.10 \mathrm{~m} / \mathrm{s}$ to $450{ }^{\circ} \mathrm{C}-0.25 \mathrm{~m} / \mathrm{s}$, the peak intensities of $\mathrm{Ag}$ and $\mathrm{MLG}$ increased and reached the highest values at $450{ }^{\circ} \mathrm{C}-$ $0.25 \mathrm{~m} / \mathrm{s}$. As the test condition changed from $25^{\circ} \mathrm{C}-$ $0.10 \mathrm{~m} / \mathrm{s}$ to $600{ }^{\circ} \mathrm{C}-0.30 \mathrm{~m} / \mathrm{s}$, the peak intensity of $\mathrm{O}$ gradually increased and obtained the highest value. However, the MLG peak sharply decreased when the test condition varied from $450{ }^{\circ} \mathrm{C}-0.25 \mathrm{~m} / \mathrm{s}$ to $600{ }^{\circ} \mathrm{C}-0.30 \mathrm{~m} / \mathrm{s}$. It could be that MLG was oxidized at $600{ }^{\circ} \mathrm{C}-0.30 \mathrm{~m} / \mathrm{s}$. Gedler et al. [18] investigated the TGA, DTG thermograms and heat flow curve under air atmosphere for the graphene nanoplatelets and found that the decomposition of graphene occurred in the presence of air and produced $\mathrm{CO}$, $\mathrm{CO}_{2}$ and $\mathrm{H}_{2} \mathrm{O}$. The weight losses at $351{ }^{\circ} \mathrm{C}(5 \mathrm{wt} \%)$ and $700{ }^{\circ} \mathrm{C}(50 \mathrm{wt} \%)$ were also observed. It showed that MLG should be oxidized at $600{ }^{\circ} \mathrm{C}$ to form $\mathrm{CO}$ and $\mathrm{CO}_{2}$.

Figure 8 shows typical FESEM microstructures of worn surfaces obtained after tests at $300{ }^{\circ} \mathrm{C}-0.20 \mathrm{~m} / \mathrm{s}, 450{ }^{\circ} \mathrm{C}-$ $0.25 \mathrm{~m} / \mathrm{s}$ and $600{ }^{\circ} \mathrm{C}-.30 \mathrm{~m} / \mathrm{s}$. At $300{ }^{\circ} \mathrm{C}-0.20 \mathrm{~m} / \mathrm{s}$, as shown in Fig. 8a, little MLG was ground out to worn surface and the migration phenomenon of $\mathrm{Ag}$ was not obvious at the lower temperature and sliding speed, leading to the formation of the incomplete tribofilms. At $450{ }^{\circ} \mathrm{C}-$ $0.25 \mathrm{~m} / \mathrm{s}$, as shown in Fig. 8b, MLG was ground out of TMACs to form a high-strength skeleton on worn surface. $\mathrm{Ag}$ was migrated to worn surface and combined with the MLG skeleton to form intact and high-strength tribofilms. The tribofilms had high strength for the enhancing effect of MLG skeleton, leading to the small wear rate of TMACs. Moreover, the tribofilms also had good anti-friction abilities for the lubricating effect of Ag, resulting in the decrease in friction resistance and friction coefficient. Hence, tribological performance of TMACs at $450{ }^{\circ} \mathrm{C}-$ $0.25 \mathrm{~m} / \mathrm{s}$ was better than that at $300{ }^{\circ} \mathrm{C}-0.20 \mathrm{~m} / \mathrm{s}$. At $600{ }^{\circ} \mathrm{C}-0.30 \mathrm{~m} / \mathrm{s}$, as shown in Fig. 8c, MLG lost the 


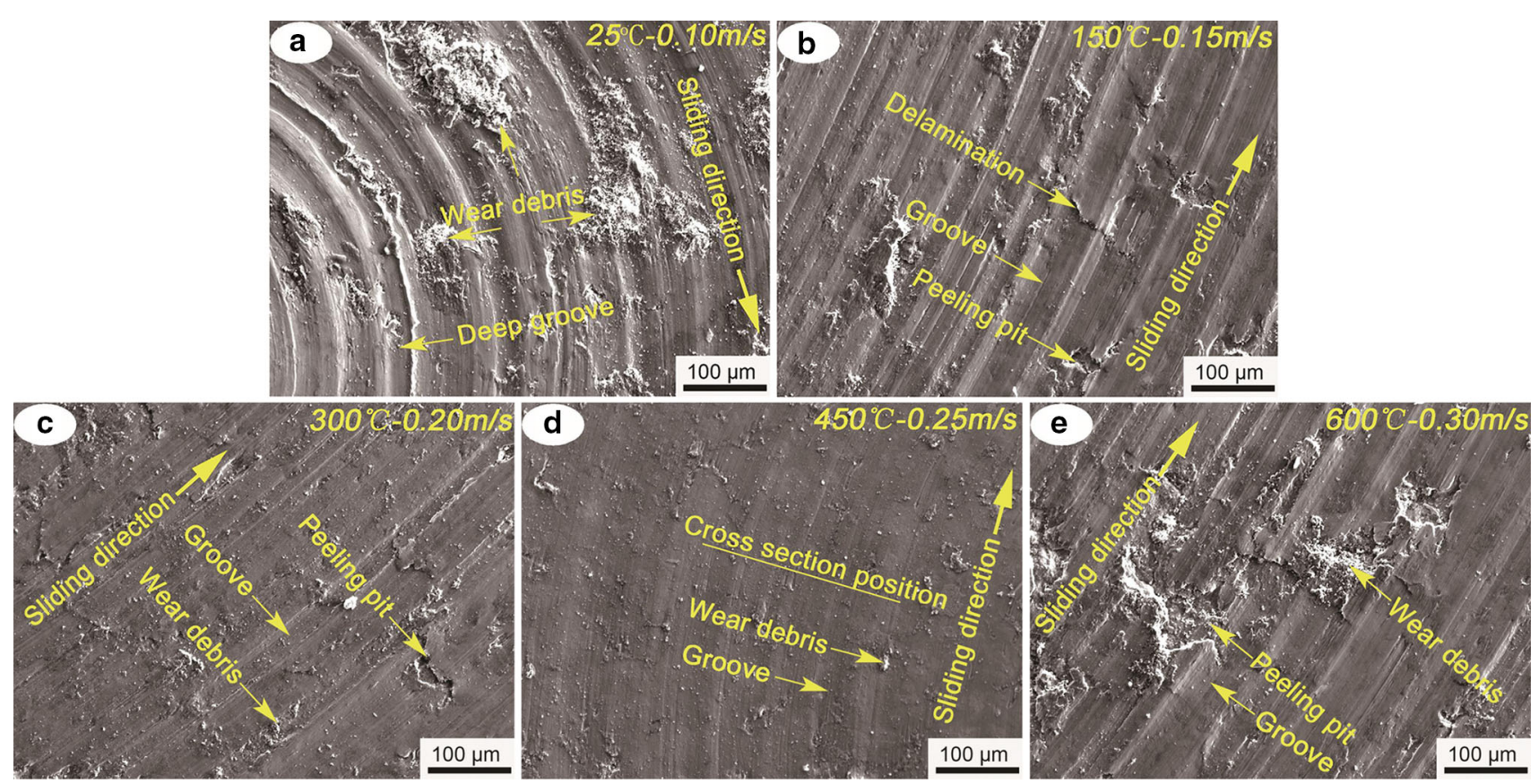

Fig. 6 Typical EPMA micrographs of worn surfaces obtained after 80 -min tests at $25{ }^{\circ} \mathrm{C}-0.10 \mathrm{~m} / \mathrm{s} \mathrm{a}, 150{ }^{\circ} \mathrm{C}-0.15 \mathrm{~m} / \mathrm{s} \mathbf{b}, 300{ }^{\circ} \mathrm{C}-0.20 \mathrm{~m} / \mathrm{s} \mathbf{c}$, $450{ }^{\circ} \mathrm{C}-0.25 \mathrm{~m} / \mathrm{s} \mathrm{d}, 600{ }^{\circ} \mathrm{C}-0.30 \mathrm{~m} / \mathrm{s}$ e
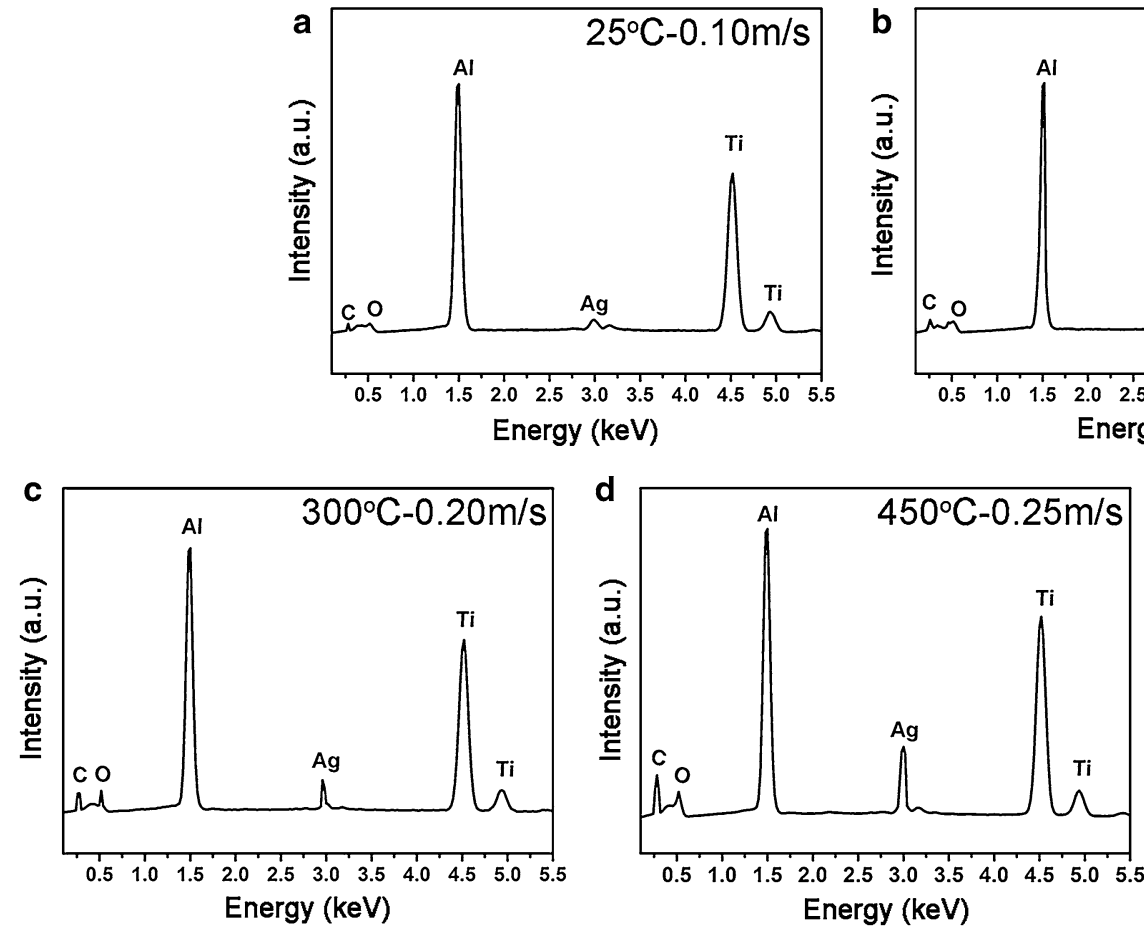

Fig. 7 EDS analysis results of worn surfaces obtained after 80 -min tests at $25{ }^{\circ} \mathrm{C}-0.10 \mathrm{~m} / \mathrm{s} \mathrm{a}, 150{ }^{\circ} \mathrm{C}-0.15 \mathrm{~m} / \mathrm{s} \mathrm{b}, 300{ }^{\circ} \mathrm{C}-0.20 \mathrm{~m} / \mathrm{s} \mathbf{c}, 450{ }^{\circ} \mathrm{C}-$ $0.25 \mathrm{~m} / \mathrm{s} \mathrm{d}, 600^{\circ} \mathrm{C}-0.3 \mathrm{~m} / \mathrm{s} \mathrm{e}$

enhancing role for the oxidation and $\mathrm{Ag}$ became excessively soft at $600{ }^{\circ} \mathrm{C}$, leading to the formation of the weak tribofilms. The weak tribofilms were easily broken under applied load, resulting in the formation of peeling pits.
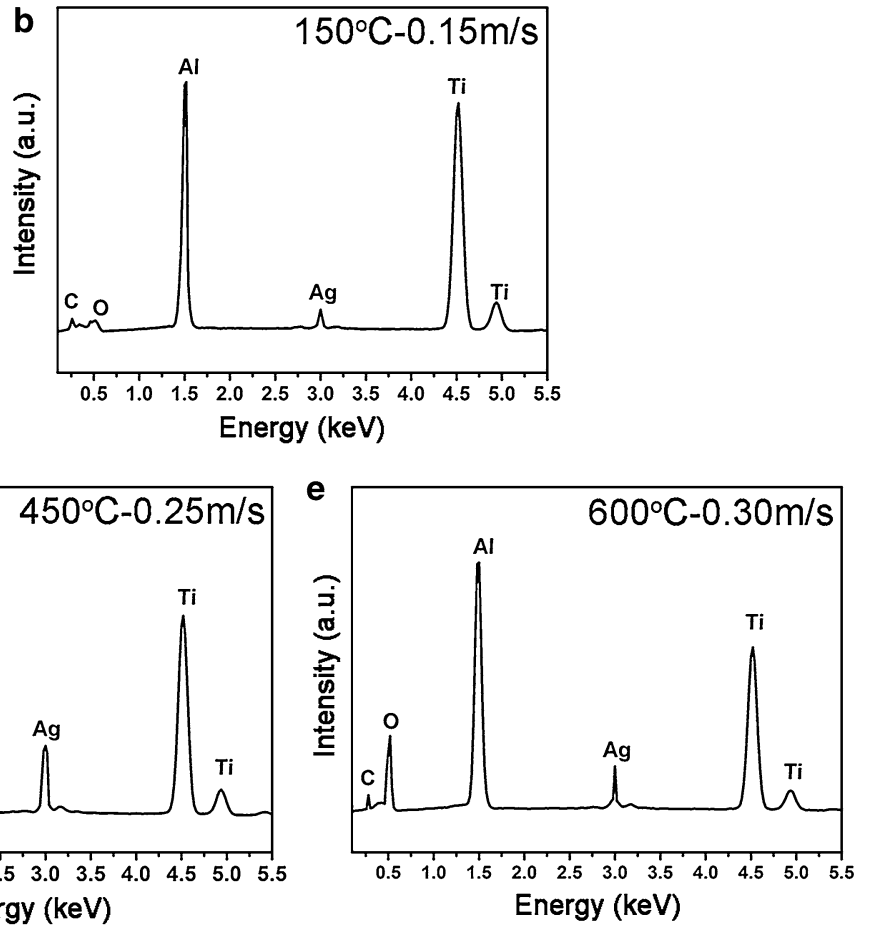

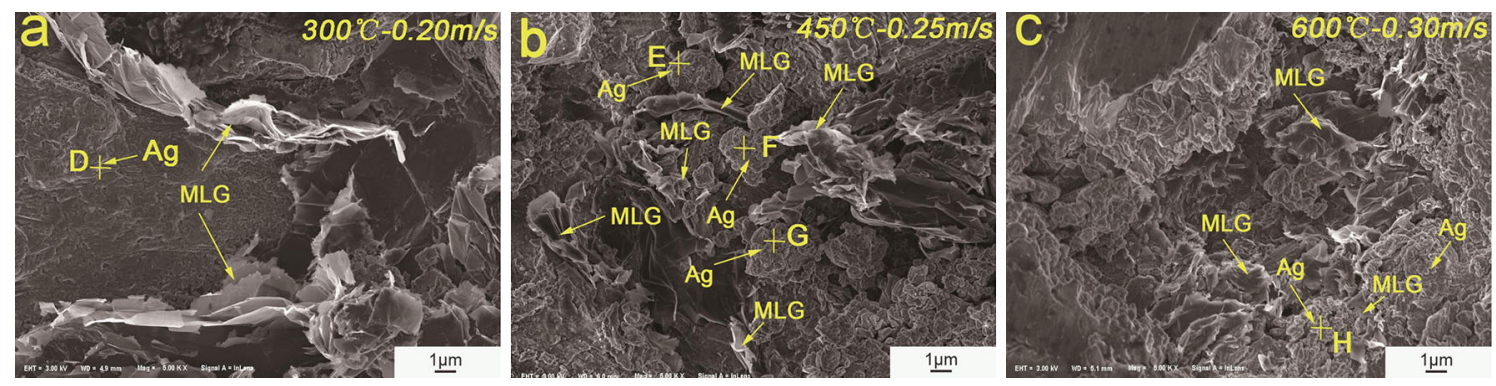

Fig. 8 Typical FESEM morphologies of worn surfaces of TMACs obtained after tests at $300{ }^{\circ} \mathrm{C}-0.20 \mathrm{~m} / \mathrm{s}$ a, $450{ }^{\circ} \mathrm{C}-0.25 \mathrm{~m} / \mathrm{s} \mathbf{b}, 600{ }^{\circ} \mathrm{C}-$ $0.30 \mathrm{~m} / \mathrm{s} \mathrm{c}$

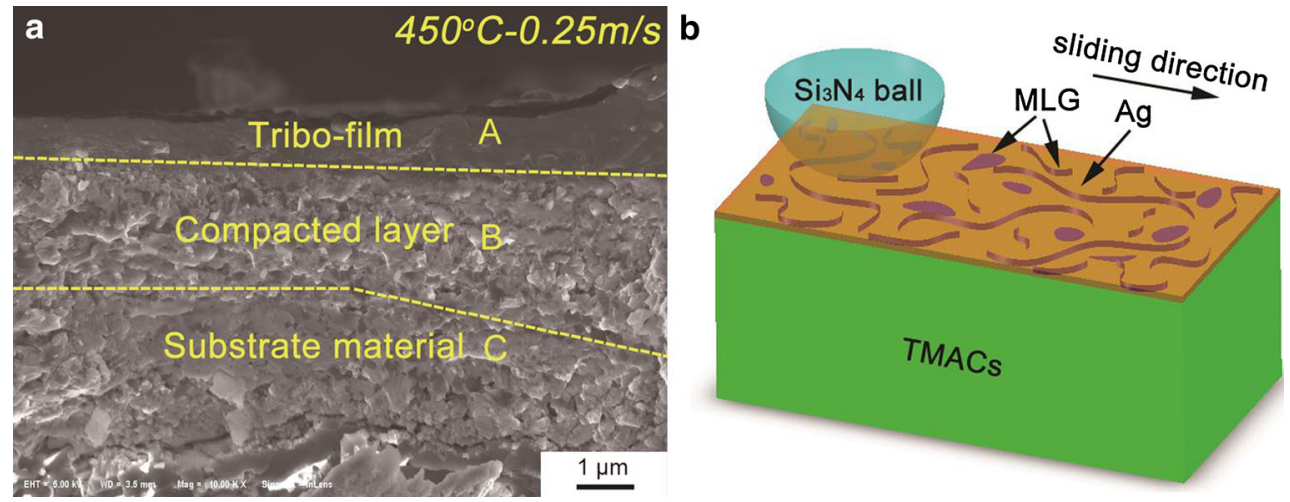

Fig. 9 Cross section of worn scar a and diagram of tribofilms b on the worn surface at $450{ }^{\circ} \mathrm{C}-0.25 \mathrm{~m} / \mathrm{s}-12 \mathrm{~N}$

the formation of the intact and high-strength tribofilms containing Ag and MLG on the worn surface. At $450{ }^{\circ} \mathrm{C}-$ $0.25 \mathrm{~m} / \mathrm{s}$, MLG was ground out of TMACs to play the role as the high-strength skeleton on worn surface. Ag was migrated on the worn surface with the help of the sliding $\mathrm{Si}_{3} \mathrm{~N}_{4}$ ball to work as a lubricant. During the testing process, Ag was combined with MLG to form the highstrength and intact tribofilms on the worn scar (see Fig. 9a). Figure 9b shows the diagram of tribofilms on the worn surface. As shown in Fig. 9b, MLG worked as a highstrength skeleton to enhance the strength of the tribofilms, leading to the less wear rate $\left(1.70 \times 10^{-4} \mathrm{~mm}^{3} \mathrm{~N}^{-1} \mathrm{~m}^{-1}\right)$. $\mathrm{Ag}$ worked as a lubricant for its low shear strength, resulting in the low friction resistance and friction coefficient (0.29). At $300{ }^{\circ} \mathrm{C}-0.20 \mathrm{~m} / \mathrm{s}$, the migration phenomenon of $\mathrm{Ag}$ was not obvious for the low temperature, and little MLG was ground out of TMACs at low sliding speed, leading to the formation the incomplete tribofilms. Hence, the tribological performance at $300{ }^{\circ} \mathrm{C}-0.20 \mathrm{~m} / \mathrm{s}$ was worse than that at $450{ }^{\circ} \mathrm{C}-0.25 \mathrm{~m} / \mathrm{s}$. At $600{ }^{\circ} \mathrm{C}-$ $0.30 \mathrm{~m} / \mathrm{s}$, MLG was oxidized, and Ag became excessively soft at the high temperature. Hence, the tribofilm was weak at $600{ }^{\circ} \mathrm{C}-0.30 \mathrm{~m} / \mathrm{s}$. The weak tribofilms were broken under applied load, resulting in the formation of peeling pits and the increase in friction coefficient and wear rate.

\section{Conclusions}

The tribological behavior of TiAl-multilayer graphene-Ag composites (TMACs) prepared by spark plasma sintering, sliding against a 6-mm-diameter $\mathrm{Si}_{3} \mathrm{~N}_{4}$ ball on a ball-ondisk tribometer, was investigated at $25^{\circ} \mathrm{C}-0.10 \mathrm{~m} / \mathrm{s}$, $150{ }^{\circ} \mathrm{C}-0.15 \mathrm{~m} / \mathrm{s}, 300{ }^{\circ} \mathrm{C}-0.20 \mathrm{~m} / \mathrm{s}, 450{ }^{\circ} \mathrm{C}-0.25 \mathrm{~m} / \mathrm{s}$ and $600{ }^{\circ} \mathrm{C}-0.30 \mathrm{~m} / \mathrm{s}$. The conclusions were as follows:

1. TMACs showed the smallest friction coefficient $(0.29)$ and wear rate $\left(1.70 \mathrm{~mm}^{3} \mathrm{~N}^{-1} \mathrm{~m}^{-1}\right)$ at $450{ }^{\circ} \mathrm{C}-0.25 \mathrm{~m} /$ $\mathrm{s}$, compared to those at $25^{\circ} \mathrm{C}-0.10 \mathrm{~m} / \mathrm{s}, 150{ }^{\circ} \mathrm{C}-$ $0.15 \mathrm{~m} / \mathrm{s}, 300{ }^{\circ} \mathrm{C}-0.20 \mathrm{~m} / \mathrm{s}$ and $600{ }^{\circ} \mathrm{C}-0.30 \mathrm{~m} / \mathrm{s}$, .

2. The good tribological performance of TMACs at $450{ }^{\circ} \mathrm{C}-0.25 \mathrm{~m} / \mathrm{s}$ was attributed to the formation of the intact and high-strength tribofilms containing $\mathrm{Ag}$ and MLG.

3. At $450{ }^{\circ} \mathrm{C}-0.25 \mathrm{~m} / \mathrm{s}$, during the sliding process, MLG was ground out of TMACs from worn surface, resulting in the formation of a high-strength skeleton. $\mathrm{Ag}$ was migrated from worn surface and combined with the MLG skeleton, leading to the formation of the high-strength tribofilms.

4. The strength of tribofilms of TMACs at $450{ }^{\circ} \mathrm{C}-$ $0.25 \mathrm{~m} / \mathrm{s}$ was enhanced by MLG skeleton, leading to the decrease in wear rate. Ag worked as a lubricating 
phase to decrease the frictional resistance and friction coefficient. Consequently, TMACs showed the excellent tribological performance at $450{ }^{\circ} \mathrm{C}-0.25 \mathrm{~m} / \mathrm{s}$.

Acknowledgements This work is supported by the National Natural Science Foundation of China (51275370); Self-determined and Innovative Research Funds of WUT (135204008); the Fundamental Research Funds for the Central Universities (2016-YB-017 and 2016-zy-014). Authors are grateful to M.J. Yang, S.L. Zhao and W.T. Zhu in Material Research and Test Center of WUT for their kind help with EPMA and FESEM.

\section{References}

[1] J. Cheng, F. Li, Z.H. Qiao, S.Y. Zhu, J. Yang, W.M. Liu, Mater. Des. 84, 235 (2015)

[2] A.E. Jiménez, M.D. Bermúdez, Tribol. Lett. 40, 246 (2010)

[3] J. Cheng, J. Yang, J.Q. Ma, Q.L. Bi, X.H. Zhang, L.C. Fu, F. Li, S.G. Zhu, W.M. Liu, Tribol. Lett. 46(3), 241 (2012)

[4] A.R. Rastkar, T. Bell, Wear 258, 1616 (2005)

[5] X.F. Yang, J. Cheng, P.L. Song, S.R. Wang, L.Y. Yang, Y.J. Wang, K. Mao, Acta Metall. Sin. (Engl. Lett.) 26, 157 (2013)

[6] W.T. Zhang, L.Z. Du, H. Lan, C.B. Huang, W.G. Zhang, Acta Metall. Sin. (Engl. Lett.) 26, 435 (2013)
[7] J.H. Ouyang, S. Sasaki, T. Murakami, K. Umeda, Wear 258, 1444 (2005)

[8] X.L. Shi, Z.S. Xu, M. Wang, W.Z. Zhai, J. Yao, S.Y. Song, A.Q. Din, Q.X. Zhang, Wear 303, 486-494 (2013)

[9] O. Penkov, H.J. Kim, H.J. Kim, D.E. Kim, Int. J. Precis. Eng. Manuf. 15, 577 (2014)

[10] H. Wang, G.T. Xie, Z.G. Zhu, Z. Ying, Y. Zeng, Compos. Part A Appl. S 67, 268 (2014)

[11] Z.S. Xu, X.L. Shi, W.Z. Zhai, J. Yao, S.Y. Song, Q.X. Zhang, Carbon 67, 168 (2014)

[12] J. Cheng, J. Yang, X.H. Zhang, Z. Hong, J.Q. Ma, F. Li, L.C. Fu, Q.L. Bi, J.S. Li, W.M. Liu, Intermetallics 31, 120 (2012)

[13] M.A. Chowdhury, M.K. Khalil, D.M. Nuruzzaman, M.L. Rahaman, Int. J. Mech. Mechatron. Eng. 11, 53 (2011)

[14] K. Yang, X.L. Shi, W.Z. Zhai, L. Chen, A. Zhang, Q.X. Zhang, RSC Adv. 5, 44618 (2015)

[15] C.Q. Peng, B.Y. Huang, Y.H. He, Trans. Nonferrous Met. Soc. China 8, 11 (1998). (in Chinese)

[16] ASTM E92-82, Standard test method for vickers hardness of metallic materials (ASTM International, 2003)

[17] ASTM B962-08, Standard test methods for density of compacted or sintered powder metallurgy (PM) products using Archimedes' principle (ASTM International, 2008)

[18] G. Gedler, M. Antunes, V. Realinho, J.I. Velasco, Polym. Degrad. Stab. 97, 1297 (2012) 